\title{
The Effect of Working Capital Management on Corporate Profitability: Evidence from Nigerian Food Product Firms
}

\author{
Sabo Muhammad ${ }^{1}$, Rabi'U Saminu Jibril ${ }^{1}$, Usman Sani K. Wambai ${ }^{1}$, Fatima Bello Ibrahim ${ }^{2}$, Tjjani Habibu Ahmad ${ }^{3}$ \\ ${ }^{1} \mathrm{MSc}$ (Accounting), Department of Accountancy, Kano State Polytechnic, Nigeria \\ ${ }^{2} \mathrm{PhD}$ Accounting (In View), Department of Accounting, North West University, Kano, Nigeria \\ ${ }^{3} \mathrm{MSc}$ (Forensic Accounting and Auditing), ACA, Internal Audit Unit, Hussaini Adamu PolytechnicKazaure, Nigeria \\ Correspondence: Rabi'U Saminu Jibril, MSc (Accounting), Department of Accountancy, Kano State Polytechnic, \\ Nigeria.
}

Received: March 23, 2015

Accepted: April 8, 2015

Available online: May 26, 2015

doi:10.11114/afa.v1i2.842

URL: http://dx.doi.org/10.11114/afa.v1i2.842

\begin{abstract}
The paper examines the impact of working capital management on corporate profitability through the periods of 2008 to 2012. The total of seven firms listed on the floor of the Nigerian Stock Exchange was studied, using secondary data generated from annual reports and accounts of the sampled companies and the Nigerian Stock Exchange Fact book. The data were analyzed by means of descriptive statistics and GLS regression analysis using STATA 11. The study finds a positive relationship among Average Collection Period (ACP), Current Ratio (CR) and the size of the firm (LOGSIZE) with Profitability and a negative relationship with Inventory Turnover Period (ITP), Average Payment Period (APP). The paper therefore recommends that cash collected should be re-invested into short-term investment to generate profits and fund left idle in the cash or excessive liquidity is costly and do not lead to profitability.
\end{abstract}

Keywords: Working Capital, Corporate Profitability, Food Product Firms

\section{Introduction}

Working capital is refers to the management of current assets and current liabilities, it is therefore important for every enterprise to plan for adequate funds to meet $\mathrm{d}$ The Nigeria day-to-day expenditure requirements of the business. Working capital management is a process of planning for the acquisition and usage of short term assets and liabilities. Working capital is the flow of readily available funds necessary required for continuous operations of an enterprise. Working capital management therefore is a process of determining the firms' policy in planning for its current assets and liabilities holdings in financing its routine operations. It is important to note that among the resource that organization owned. Working capital is generally significant for any organizational setting that requires sound attention, appropriate planning and management. As resources available to organizations are scarce, it is believed that the management of an organization's working capital has a fundamental role to play in the achievement of profitability and overall performance of such an entity. This entail that a firm's liquidity perform to a large extent determine its profitability. In this vein, Charitou, Elfani and Lois (2010) believes that efficient use of the firm's resources leads to increased profitability and reduces volatility which leads to the reduction in default risk and thus improves the firm's value.

Empirical studies on the effect of working capital management on corporate performance have shown that managers can improve firms' profitability through efficient management of working capital. Deloof (2003) in Grill, Biger and Mathur (2010) posit that way in which working capital is managed has a significant impact on both cash flow and profitability of enterprises. He further explained that the longer the time span between the expenditure incurred in the purchase of raw materials or machandise and the collection of sales proceeds, the larger the investment in working capital. A long conversion cycle will lead to higher sales volume and therefore increase profits but will also decrease profits when the cost of investment in working capital rises faster than the benefits of holding more inventories and or granting more trade credits to buyers.

One can then articulate decisions concerning working capital must not be taken for granted. To this end, Arnold (2005) stress that if there is little working capital, it results in inventories, finished goods and customer credit not being 
available in sufficient quantity. On the other hand, if there are excessive levels of working capital, the firm has unnecessary additional cost: the cost of tying up funds plus the storage, ordering and handling costs of being overburdened with stock. This creates a sort of imbalance in the working capital components, making their management difficult which in practice is a situation that firms are confronted with. As a result therefore, the ultimate goal of working capital management is to ensure that firms are able to continue their operations with sufficient cash flow that will service their long term debts and satisfy both maturing short term obligations (debt) and upcoming operational expenses. Hence, Organizations should try as much as possible to meet up with this goal so as to avoid being caught up in the trap of ineffective management of working capital components.

The objective of this research is to examine the relationship among working capital management and company's profitability with emphasis on Nigerian food product firms.

The rest of the paper is divided into four sections, section two review of related literature from previous studies. Third section of the study describes methodology used for examining the relationship between working capital and profitability. Section four comprises of the empirical results and discussion. Fifth section is conclusion and recommendation.

\section{Literature Review}

While long term financial decisions involve cash flows over an extended period of time, short term decisions, on the other hand, relate to cash flows within a year or within an operating cycle. Working capital being the value of investment in short term and easily convertible assets therefore, is the key difference among the long term and short term financial management in terms of cash flow timings.

Pandey (2005) broadly classified working capital according to components and time. He pointed out that a firm's assets components of cash, marketable securities, receivables and inventories constitute working capital; going further to explain that working capital can further be classified according to time into permanent and variable sub groupings. Since investment in working capital is required for the continuous operations of the firm, it naturally follows that the need for current assets is endless. Therefore the minimum level of current assets, which is always required to enable the firm carry on its business operations. The minimum level of working capital is the permanent working capital. It is only permanent or fixed in the sense of the size of the total investment and not in the individual components of working capital.

\subsection{Review of Related Empirical Literature}

Working capital management refers to the administration of all components of working capital such as cash, debtors and stock receivables, etc (Pandey, 2007). The importance of the working capital management function of the firm is crucial to the firm because it involves time, investment as well as growth prospects of the firm.

Several studies were conducted regarding the relationship between the management of working capital and corporate profitability. Several findings, using different data sets, variables methods of analysis unanimously agree that corporate profitability can be improved through efficient working capital management.

Deloof (2003) argue that most firms had a large amount of cash invested in working capital. It can therefore be expected that the way in which working capital is managed will have a significant impact on profitability of those firms. Using correlation and regression tests he found a significant negative relationship between gross operating income and the number of days accounts receivable, inventories and accounts payable of Belgian firms. On basis of these results he suggested that managers could create value for their shareholders by reducing the number of days' accounts receivable and inventories to a reasonable minimum. The negative relationship between accounts payable and profitability is consistent with the view that less profitable firms wait longer to pay their bills.

Similarly, Raheman and Nasr (2007) explains that working capital management has its effect on liquidity as well on profitability of the firm and hence studied the effect of different variables of working capital management including the average collection period, inventory turnover in days, average payment period, cash conversion cycle and current ratio on the net operating profitability of Pakistani firms. Debt ratio, size of the firm (measured in terms of natural logarithm of sales) and financial assets to total assets ratio were used as control variables. Their results showed significant negative relationship between variables of the working capital management and profitability of the firm. It means that as the cash conversion cycle increases it will lead to decreasing profitability of the firm, and managers can create a positive value for the shareholders by reducing the cash conversion cycle to a possible minimum level. They also found that there is a significant negative relationship between liquidity and profitability; that there is a positive relationship between size of the firm and its profitability; and significant negative relationship between debt used by the firm and its profitability. Also, Al-Debi'e (2011) examined the relationship between working capital management on corporate profitability for industrial firms in Jordan for the period of $2001-2010$. In this study the net operating profit is considered as a measure of profitability the results indicates that there is a strong negative relationship between the 
measures of working capital and the profitability.

Also, Afza and Nazir (2007) examined the relationship between aggressive and conservative working capital policies for a large sample of 205 firms in 17 sectors listed on Karachi Stock Exchange during 1998-2005. They found a negative relationship between the profitability measures of firms and degree of aggressiveness of working capital investment and financing policies. Also Ngwenya (2012) investigated the relationship between working capital management and profitability for a sample of 69 companies listed on the Johannesburg stock exchange for the period of 1998 to 2008. This study for analysis the data used regression analysis and Pearson correlation. His results showed a significant negative relationship between profitability and CCC, and a positive significant relationship between accounts payable and profitability.

In the same vein, Sarbapriya Ray (2012) the study assess the relationship among working capital management components and the profitability for the Indian manufacturing firms using a sample of 311 Indian manufacturing firms through the periods of 1996/1997 to 2009/2010 and have studied the effect of different variables of working capital management including the average collection period, inventory turnover in days, average payment period, cash conversion cycle and current ratio, debt ratio, size of the firm and financial assets to total assets ratio on the net operating profitability of Indian firms. The result suggests a strong negative relationship between the measures of working capital management including the number of days accounts receivable and cash conversion cycle, financial debt ratio with corporate profitability.

Also, Zubair and Muhammad (2013) examined the impact of working capital management on profitability for a sample of 21 listed cement companies in Karachi Stock Exchange, for the period of 2004 - 2010. Empirical findings showed that there is a significant negative relationship between working capital management on profitability of firms. Similarly, Other researchers also conducted their study on the impact of working capital management on corporate profitability in different environment and countries and they all arrived at common and similar conclusion Eljelly (2004), Gill, Biger and Mathur (2010), Charitou, Elfani and Lois (2010), Mathuva (2010), Rahman (2011), Alipour (2011), Usama (2012), , Ali and Ali (2012), Onwumere, Ibe and Ugbam (2012), Uremadu, Egbide and Enyi (2012), Oladipupo and Okafor (2013)

In contrast, Lazaridis and Tryfonidis (2006) sampled 131 listed firms in Athens Stock Exchange for the period of 2001 2004 and their results showed a significant relationship between operating profit and CCC and its components. The study suggested that managers can enhance the profits of firm by keeping each component of working capital on an optimal level and appropriate handling of CCC. In addition, Hamid and waqar (2013) in their paper they made an attempt to examine the efficiency of working capital management of the Pakistani firms. A sample of 100 non financial firms listed on Karachi Stock Exchange for the period of 2005 - 2009. The study found a positive relationship between profitability and working capital management and concludes that efficient working capital management plays an imperative role for the enhancement of profitability of the firms.

Similarly, Padachi (2006) examined the relationship between profitability and selected working capital management measures using 58 small manufacturing Mauritian companies over the period 1997-2003. They sub classified their sample companies into five sub-classifications for analysis purposes. The study models were estimated using the regression based framework. The dependent variable used in all models was the return on assets. The independent variables were the RCP, the ICP, the PDP, and the CCC. The models also included control variables that may have an effect on the profitability of the company, these control variables were; size, gearing ratio, working capital turnover ratio, current assets to total assets ratio, and current liabilities to total assets ratio. The results of all types of the regression models used showed that the only significant, with the expected negative sign, WCM measure is the average RCP. Size and the current assets to total assets ratio were the only significant control variables with positive signs.

Nevertheless, Owolabi and Alu (2012) explore the effective working capital management and profitability on selected manufacturing companies in Nigeria they sample 5 companies out of 32 of the population. This study for analysis the data used multivariate analysis to test the hypothesis. Their results indicated that each working capital component affected the company's level of profitability at varying rates, but, these effects when pooled together are not significant. Other researchers that made a similar and common conclusion on the relationship between working capital management and corporate profitability Barine (2012), Mansoori and Muhammad (2012), Ghaziani, Biabani and Zadeh (2012), Alavinasab and Davoudi (2013), Mehra (2013).

The above literature presents different types of impacts of working capital management on profitability for different industries in different countries. The current study examines the relationship between the working capital components on profitability in Nigerian food product firms. On the basis of these literatures done in different countries the researcher developed this methodology. 


\section{Research Methodology}

The purpose of this research is to contribute towards a very important aspect of financial management known as working capital management with reference to Nigeria. Here we will see the effect of working capital management practices and its effects on profitability of 7 food products Nigerian firms listed on the Nigerian stock Exchange for a period of five years from 2008 - 2012. This section of the article discusses the firms and variables included in the study, the distribution patterns of data and applied statistical techniques in investigating the effect of working capital management on profitability.

The data for this study is collected using the non-survey method. This is due to the fact that the accounting information required for this study is easily obtainable from the published annual reports and accounts. Accordingly, relevant balance sheet and profit and loss items: the inventory and receivables conversion periods, current ratio, creditors' payment period of the sampled companies are the variable to be studied in this work.

\subsection{Population and Sample Size}

The population of this study is made up of all the quoted Nigerian food product companies quoted on the Nigerian Stock Exchange, their years of Incorporation and years of listing are as follows:

Table 1. Study Population

\begin{tabular}{llcc}
\hline S/N & COMPANY NAME & YEAR OF INCORPOR. & YEAR OF LISTING \\
\hline 1 & FLOUR MILLS OF NIGERIA PLC & 1960 & 1979 \\
2 & N. N. F. M. PLC & 1971 & 1978 \\
3 & DANGOTE SUGAR REFINERY PLC & 2005 & 2007 \\
4 & NATIONAL SALT COMPANY PLC & 1973 & 1992 \\
5 & UNION DICON PLC & 1992 & 1993 \\
6 & MULTI-TREX PLC & 1999 & 2010 \\
7 & HONEY WELL FLOUR PLC & 2008 & 2009 \\
8 & DANGOTE FLOUR MILLS PLC & 2006 & 2008 \\
9 & BIG TREAT PLC & 1991 & 2007 \\
10 & PS MANDRIES & 1949 & 1979 \\
11 & UTC NIGERIA PLC & 1969 & 1972 \\
\hline
\end{tabular}

Source: Generated by the researcher from the NSE 2011/2012 fact book

Table I is about the total population of the study, out of which the working population is arrived at. The criteria used for choosing the working population are listing latest by 2007 and the availability of data for the period under study that is 2008 to 2012. The companies met with these criteria are listed in table 2.

Table 2. Working Population

\begin{tabular}{llcc}
\hline S/N & COMPANY NAME & YEAR OF INCORPOR. & YEAR OF LISTIN \\
\hline 1 & FLOUR MILLS OF NIGERIA PLC & 1960 & 1979 \\
2 & N. N. F. M. PLC & 1971 & 1978 \\
3 & DANGOTE SUGAR REFINERY PLC & 2005 & 2007 \\
4 & NATIONAL SALT COMPANY PLC & 1973 & 1992 \\
5 & UNION DICON PLC & 1992 & 1993 \\
6 & PS MANDRIES & 1949 & 1979 \\
7 & UTC NIGERIA PLC & 1969 & 1972 \\
\hline
\end{tabular}

Source: Generated by the researcher from table 1.

The population of the study is therefore redefined to comprise the 7 food products companies. The entire population is studied, without any need to make sampling. Studying the entire population has the advantage of eliminating sampling problems and bias, and confers more confidence in the findings of the study.

\subsection{Variables}

The statistical method of GLS regression analysis was employed in the conduct of this study. This technique of data 
analysis is used in ascertaining the effects of the independent variables on the dependent variable. Choice and selection of variables is influence by the past research and different study conducted by different scholars on working capital management.

\subsubsection{The dependent variable and its measurement}

The dependent variable in this study is the companies's profitability. This is in harmony with the works of Afza and Nazir (2007), and Falope and ajilore (2009), the return on assets was adopted as proxy for profitability. For the purpose of this study return on assets is defined as net income before taxes by total assets consistence with the work of Dong and $\mathrm{Su}(2010)$.

\subsubsection{The independent variables and their measurements}

The independent variables of Average Collection period, Average Payment Period as well as inventory turnover period as measures of working capital management, were commonly used in previous studies of Padachi (2006), Raheman and Nasir (2007), and Falope and Ajilore (2009), and the Current Ratio being the traditional measure of liquidity as another variable. These are the key variables that influence working capital management.

The independent variables have been computed as follows:

Inventory Turnover Period $=\underline{\text { Average Inventory X } 365}$

Cost of Sales

Average Collection Period $=\underline{\text { Average Debtors X } 365}$

Sales

Average Payment Period $=\underline{\text { Average creditors X } 365}$

Cost of Sales

Current Ratio $=\underline{\text { Current Assets }}$

Current Liabilities

\subsubsection{Control Variables}

In order to have an appropriate analysis of the effect of working capital management on the profitability of firms, different studies have incorporated the use of other variables which also affect firm's profitability. The study takes into consideration one control variable. The measure of the natural logarithms of total assets of the companies is adopted for size as one of the control variables. This is consistence with the works of Owolabi and Alu (2012), Dong and Su (2010).

\subsection{Model Specification}

In line with the previous researches the researcher adopts the model of Hamid and waqar (2013) in determining the effect of working capital management on corporate profitability among Nigerian food product companies as follows:

$$
R O A=a+\beta 1(\mathrm{TTP})+\beta 2(\mathrm{ACP})+\beta 3(\mathrm{APP})+\beta 4(\mathrm{CR})+\beta 5(\mathrm{LOS})+\varepsilon
$$

Where:

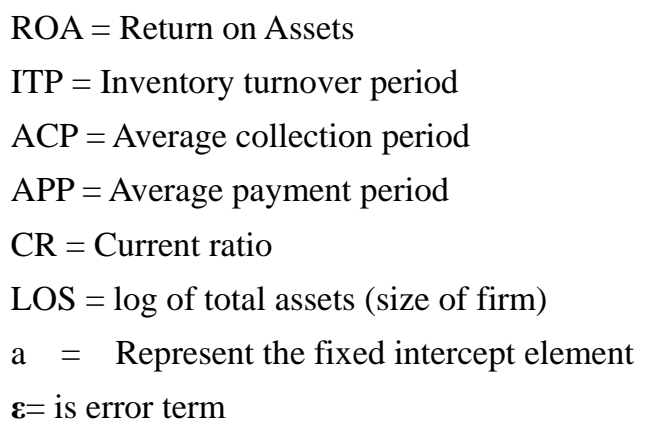

\section{Results and Discussion}

The statistical software of Stata (version 11) was used to analyse the relationship among variables of the study. Descriptive statistic merely represents the statistical attributes of the variables in the study model. Table 3 below 
provides such statistics. All the variables were computed from the relevant balance sheets and income statements of the sampled companies.

Table 3. Descriptive Statistics of Variable

\begin{tabular}{lccccc}
\hline Variable & Min. & Max. & Mean & Std. Dev. & No. \\
\hline ROA & -1.26882 & 0.5183019 & -0.0171061 & 0.408411 & 35 \\
ITP & 0.0 & 255.43930 & 45.213090 & 55.81706 & 35 \\
ACP & 0.0 & 132.96630 & 26.025240 & 28.57686 & 35 \\
APP & 5.582518 & 5193.1310 & 603.46230 & 1437.359 & 35 \\
CR & 0.0041883 & 2.4395540 & 1.4060250 & 0.7731933 & 35 \\
LOGSIZE & 4.816155 & 8.2368120 & 6.5947340 & 1.078402 & 35 \\
\hline
\end{tabular}

Source: Generated by the researcher from the Annual Reports and Accounts of the sampled companies, using Stata (version 11).

Table 3, above reveals that the return on assets of the seven food product companies over the five year period ranged from a negative return of $127 \%$ to a maximum of $52 \%$. This means that for every one Naira worth of net investment, the sector had at worst made a loss of N1.27 and had at best earned a maximum of N0.52. and every firm in the sector could made an average loss of $2 \%$ on its investment with a high degree of risk, as returned can vary at both sides of the scale by the large margin of $41 \%$. While it takes an average of 45 days to convert inventories into sales others could not turn inventories into sales till after 255 days. The credit period the companies granted their clients averaged 26 days while they paid their creditors in 603 days on the average, whereas, their debtors could remain outstanding for a maximum of 133 days. The current ratio reveals that firms' investment in current assets covered only $141 \%$ and current liabilities with a $77 \%$ variability range.

In an effort to establish the nature of the correlation between the dependent and the independent variables, and also to ascertain whether or not multi-collinearity exists as a result of the correlation between variables, table 4 is incorporated for the purpose of analysis. The correlation matrix in table 4 provides an insights into which of the independent variables are related to the dependent variable.

Table 4. Correlation Matrix

\begin{tabular}{|c|c|c|c|c|c|c|}
\hline Variable & ROA & ITP & $\mathrm{ACP}$ & APP & $\mathrm{CR}$ & LOGSIZE \\
\hline ROA & 1.0000 & & & & & \\
\hline ITP & 0.1132 & 1.0000 & & & & \\
\hline $\mathrm{ACP}$ & 0.2505 & 0.8754 & 1.0000 & & & \\
\hline APP & -0.7940 & -0.2565 & -0.3244 & 1.0000 & & \\
\hline $\mathrm{CR}$ & 0.7662 & 0.4806 & 0.4760 & -0.6997 & 1.0000 & \\
\hline LOGSIZE & 0.6797 & -0.2673 & -0.2307 & -0.6307 & 0.4244 & 1.0000 \\
\hline
\end{tabular}

Source: Generated by the researcher from the Annual Reports and Accounts of the sampled companies, using Stata (Version 11)

The correlation matrix as per table 4 above shows the relationship between all pairs of independent variables used in the regression model. It reveals that all the independent variables have positive correlation with the dependent variable with exception of App, even though some of these components of working capital contribute insignificantly to profitability of companies. The values are on the diagonal are all 1.0000 which shows that each variable is perfectly correlated with itself. Though, all the independent variables have a positively correlated with ROA with exception of APP, this shows that as the ITP, ACP, CR, LOGSIZE increases the profitability of the firms increases and vice versa. On the other hand, the negative relationship that exists between the APP, and ROA indicate that there is an inverse relationship between the APP and the profitability.

The following table represents the results of TV and VIF for the working capital components. 
Table 5. Multicolnierity Test

\begin{tabular}{llr}
\hline Variable & VIF & 1/VIF (TV) \\
\hline ITP & 4.82 & 0.207327 \\
ACP & 4.77 & 0.209776 \\
APP & 3.10 & 0.322614 \\
CR & 2.88 & 0.347742 \\
LOGSIZE & 2.66 & 0.375886 \\
\hline Mean VIF & 3.65 &
\end{tabular}

Source: Generated by the researcher from the Annual Reports and Accounts of the sampled companies, using Stata (Version 11).

From the table above TV ranges from 0.207327 to 0.375886 which suggests non multi-collinearity feature. Multi-collinearity feature exists when the value of TV is less than 0.20 (as cited in Kurawa and Kabara, 2014). The VIF which is simply the reciprocal of TV range 2.66 to 4.82 , this indicates of multi-collinearity.

\subsection{Regression Result}

Regression model was developed to test the linear relationship between dependent and independent variables. To test the quality of the linear fit to the model, the researcher calculated the coefficient of multiple as shown in the table below:

Table 6. Fixed-effects GLS Regression

$\mathrm{ROA}=-.09862943-.0035866 \beta_{1}+.0058547 \beta_{2}-.0000757 \beta_{3}+.2697301 \beta_{4}-.0978705 \beta_{5}+\varepsilon$

\begin{tabular}{|c|c|c|c|c|c|c|}
\hline ROA & & Coefficients & & Std. Errors & $\mathrm{Z}$ & $\mathrm{P}>\mathrm{IZI}$ \\
\hline ITP & & -0.0035866 & & 0.0012459 & -2.88 & 0.004 \\
\hline $\mathrm{ACP}$ & & 0.0058547 & & 0.0024193 & 2.42 & 0.016 \\
\hline APP & & -0.0000757 & & 0.0000388 & -1.95 & 0.051 \\
\hline CR & & 0.2697301 & & 0.0667984 & 4.04 & 0.000 \\
\hline LOGSIZE & & 0.0978705 & & 0.0497935 & 1.97 & 0.049 \\
\hline Constant & & -0.9862943 & & 0.3565193 & -2.77 & 0.006 \\
\hline \multirow[t]{3}{*}{ R-square } & Within & & 0.0168 & & & \\
\hline & Between & & 0.9861 & & & \\
\hline & Overall & & 0.8257 & & & \\
\hline Probability & & & 0.000 & & & \\
\hline
\end{tabular}

Source: Generated by the researcher from the Annual Reports and Accounts of the sampled companies, using Stata (Version 11).

The coefficient of determinations "R-Square" shows $82.57 \%$ indicating that the variables considered in the model accounts for about $82.57 \%$ change in the dependent variable that is ROA, while the remaining $17.43 \%$ is as a result of other variables not addressed by this model. The results of this regression indicate that the relationship between ROA and ITP is negative and significant, this can be justified with the negative " $\mathrm{z}$ " value of -2.88 and $\mathrm{p}>|\mathrm{z}|$ of 0.004 . Likewise the results of negative coefficient of -0.0035866 is proving that, an increase in ITP by one more days, while other remaining variables remains constant decreases the profitability of firms. This result is consistent with the findings of Afza and Nazir (2007) and Debi'e (2011). Also the relationship between ROA on one hand and APP on the other hand is negative but not significant; this can be justified through the negative "z" value of -1.95 , and 0.051 it has been also validate by the negative coefficient of -0.0000757 . This implies that APP has an inverse relationship with ROA. This result is consistence with the findings Uremadu and Egbide (2012) and Padachi (2006).

However, the relationship between ROA on one hand and ACP, CR and SIZE is positive and significant, this can be vindicated by the positive " $\mathrm{z}$ " value of $2.42,4.04$ and 1.97 , and the $\mathrm{P}>|\mathrm{z}|$ of $0.016,0.000$ and 0.049 , so it has been also confirmed by the positive coefficient of $0.0058547,0.2697301$ and 0.0978705 respectively. This shows that the increase in ACP CR and SIZE while other variables remains constant the ROA will increased and vice versa. The findings is consistent with Padachi (2006) and Owolabi and Alu (2012).

\section{Conclusions and Recommendations}

Working capital management is important part in firm financial management decision. The ability of the firm to continuously operate in longer period depends on how they deal with investment in working capital. The optimal of 
working capital management could be achieved by firms that manage the tradeoff between profitability and liquidity. The study finds that there is a strong negative relationship between the measures of working capital management including inventory turnover period, and an insignificant negative relationship with average payment period with corporate profitability. The finding indicates that the higher the period it takes firm to convert their inventory into sales the lower the profitability of the firms. Also the negative relationship that exist between average payment period and profitability indicates that the more time it its firms to pay their creditors the less profitability, this shows that either delay payments were left idle not invested for increased yields or profit or that delay payments have made defaults from credit purchases hence most firms cannot meet up demands for supplies of goods ordered by customers due to shortage of stock of raw materials as such reducing sales turnover or volume and profits there-from. The conclusions are in confirmation with Uremadu and Egbide (2012), Afza and Nazir (2007) and Debi'e (2011).

However, the finding indicates that there is a positive relationship between average collection period, current ratio and the size with profitability. That is, as the current ratio and size of the firms' increases the profitability of firms' increases in the same direction, hence, more sizeable firms makes more profit compared with smaller firms. But the relationship between the average collection period and profitability is positive too, indicating that this should not have been the case. This happen as the firms collect their receivable from their debtors they left the fund idle without re-investing the fund to generate returns or profits. The conclusions is in line with Padachi (2006), Uremadu and Egbide (2012) and Owolabi and Alu (2012).

On the basis of the findings of the study the paper conclude that profitability can be enhanced if firms manage their working capital in a more efficient way. These results suggest that managers can create value for their shareholders by reducing the number day account receivable to a reasonable time. On the basis of the findings the study recommends that; cash collected should be re-invested into short-term investments to generate profits and funds left idle in the cash till or excessive liquidity is costly and do not lead to growth in yields or profitability Uremadu and Egbide (2012). The Study also established distorted significant relationship of debtors' collection period (ACP) with the level of corporate profitability among food product firms in Nigeria. Hence, the study recommend that firms should be very apt in collecting proceeds of credit sales from their debtors as good working capital management urges for quick cash collection from credit sales for quick reinvestment in short-term securities in order to boost profitability.

Therefore, it is suggested that further research be conducted on the same topic with different sector or industry, and extending the years of the sample.

\section{References}

Afza, T., \& Nazir, M. S. (2007). Is it better to be aggressive or conservative in managing working capital?" Journal of Quality and Technology Management, 3(2), 11-21.

Alavinasab, S. M., \& Davoudi, E. (2013). Studying the relationship between working capital management and profitability of listed companies in Tehran Stock Exchange. Business Management Dynamics, 2(7), 01-08.

Al- Debi'e, M. M. (2011). Working capital management and profitability of industrial firms in Jordan. European Journal of Economics, Finance and Administrative Sciences, 1450-2275.

Arnold, G. (2005). Corporate Financial Management 3rd Edition; England Pearson Education Limited.

Ali, A., \& Ali, S. A. (2012). Working capital management: Is it really affects the profitability? Evidence from Pakistan. Global Journal of Management and Business Research, 12, 2249-4588.

Barine, M. N. (2012). Working capital management efficiency and corporate profitability: Evidence from quoted firms in Nigeria. Journal of Applied Banking and Finance, 2(2) 1792-6580.

Charitou, M. S., Elfan, M., \& Lois, P. (2010). The effect of working capital management on firm's profitability: Empirical Evidence from an Emerging Market. Journal of Business and Economic Research, 8(12)

Deloof, M. (2003), Does Working Capital Management Affect Profitability of Belgian Firms?, Journal of Business, Finance and Accounting, 30( 3-4), 573-587. http://dx.doi.org/10.1111/1468-5957.00008

Dong, H. P., \& Su, J. (2010). The relationship between working capital management and profitability: A. Vietnam Case. International Research Journal of Finance and Economics, 49, 59-67.

Eljelly, A. M. A. (2004). Liquidity-Profitability Tradeoff: An Empirical Investigation in an Emerging Market, International Journal of Commerce and Management, 14(2), 48-61. http://dx.doi.org/10.1108/10569210480000179

Falope, O. I., \& Ajilore, O . T. (2009). Working capital management and corporate profitability: evidence from panel data analysis of selected quoted companies in Nigeria. Research Journal of Business Management, 3(3), 73-84. http://dx.doi.org/10.3923/rjbm.2009.73.84

Ghaziani, B., \& Zadeh (2012). Investigation of the Relationship between components of working capital management 
with market valuation and profitability in firms listed in Tehran Stock Exchange. Trends in Social Science, Science Road Publishing Corporation, TSS, 1(5), 55-63.

Gill, A., Biger, N., \& Mathur, N. (2010). The Relationship between working capital management and profitability: Evidence from the United States, Business and Economics Journal.

Hamid, B., \& Waqar, A. (2013). Does efficient working capital management enhance profitability of Pakistani Firms? Management and Administrative Sciences review, 2, 715-720. Iran World Applied Sciences Journal, 12(7), 1093-1099.

Kurawa, J. M., \& Kabara, A. S. (2014). Impact of Corporate Governance on Voluntary Disclosure by Firms in the Downstream Sector of the Nigerian Petroleum Industry proceedings of World Business Research Conference, Novotel World Trade Centre, Dubai, UAE 978-1-922069-48-1.

Lazaridis, I., \& Tryfonidis, D. (2006). Relationship between working capital management and profitability of listed companies in the Athens stock exchange. Journal of Financial Management and Analysis, 19, 26-25.

Mansoori, E., \& Muhammad, D. J. (2012). The effect of working capital management on firm's profitability: Evidence from Singapore. Interdisciplinary Journal of Contemporary Research in Business, 4(5).

Mathuva, D. M (2010). The influence of working capital management components on corporate profitability: A survey on Kenyan Listed Firms. Research Journal of Business Management, 4(1) 1-11. http://dx.doi.org/10.3923/rjbm.2010.1.11

Mehra, P. (2013). Effect of working capital management on the profitability of the Indian Pharmaceutical sector. International Journal of Enhanced Research in Management and Computer Applications, 2, 2219-7471.

Ngwenya, S. (2012). The relationship between working capital management and profitability of companies listed on the Johannesburg Stock Exchange. Journal of Modern Accounting and Auditing, 8(8), 1204-1213.

Oladipupo, A. O., \& Okafor, C. A. (2013). Relative contribution of working capital management to Corporate profitability and Dividend payout ratio: Evidence from Nigeria. International Journal of Business and Finance Management Research, 2053-1842, 11-20.

Onwumere, J. U. J., Ibe I. G., \& Ugbam O. C. (2012). The impact of working capital management on profitability of Nigerian Firms: A preliminary Investigation, European Journal of Business and Management, 4(15) 2222-2839.

Owolabi, S. A., \& Alu, C. N. (2012). Effective working capital management and profitability: A study of selected quoted manufacturing companies in Nigeria. Economic and Finance Review, 6(2057-0401), 55-67.

Padachi, K. (2006). Trend in Working Capital Management and its Impact on Firms' Performance: An Analysis of Mauritian Small Manufacturing Firms, International Review of Business Research Papers, 2(2), 45-58.

Pandey, I. M. (2007). Financial Management, Ninth Edition, New Delhi; Vikas Publishers

Raheman A., \& Nasr, M. (2007). Working Capital Management And Profitability - Case Of Pakistani Firms. International Review of Business Research Paper, 3(1), 279-300.

Rahman M. M. (2011). Working capital management and profitability: A study on Textiles Industry ASA University Review, 5(1).

Saleem, Q., \& Rehman, R. U. (2011), Impacts of liquidity ratios on profitability: Case of oil and gas companies of Pakistan Interdisciplinary Journal of Research in Business, 1(7), 95-98.

Sarbapriya, R. (2012). Evaluating the impact of working capital management components on corporate profitability: Evidence from Indian Manufacturing Firms International Journal of Economic Practices and Theories, 2(3), 2247-7225.

Uremadu S. O., Egbide B., \& Enyi, P. E. (2012). Working capital management, Liquidity and Corporate profitability among quoted firms in Nigeria Evidence from productive sector. International Journal of academic Research in Accounting, Finance and Management Sciences, 2, 2225-8329.

Usama, M. (2012). Working capital management and its effect on firm's profitability and liquidity: in other foods sector of Karachi Stock Exchange. Arabian Journal of Business and Management Review, 1(12).

Zubair A., \& Muhammad, Y. G. (2013). Impact of working capital management on profitability: A case of the Pakistan Cement Industry. Interdisciplinary Journal of Contemporary Research in Business, 5(2).

\section{$(\mathrm{cc})$ EY}

This work is licensed under a Creative Commons Attribution 3.0 License. 